\title{
Formation characterization and rheological properties of zirconia and ceria-stabilized zirconia
}

\author{
Arvind K. Nikumbh*, Parag V. Adhyapak \\ Department of Chemistry, University of Pune, Ganeshkhind, India; *Corresponding Author: aknik@chem.unipune.ernet.in
}

Received 17 February 2010; revised 3 May 2010; accepted 8 May 2010.

\begin{abstract}
Zirconia and ceria-stabilized zirconia (12Ce-TZP) were synthesized by the dicarboxylate coprecipitation technique such as fumarate, succinate, tartarate and adipate. The formation of these dicarboxylate precursors was studied by elemental analysis, thermal analysis and infrared spectroscopy. The precursors were further decomposed at $650^{\circ} \mathrm{C}$ for 2 hours to form respective zirconia and ceria-stabilized zirconia. The composition of these oxides was checked by Atomic absorption spectrometer and Energy dispersive $X$-ray analysis. The structural and morphological characterization of these oxides was done by using X-ray diffraction analysis, surface area, scanning electron micrographs and particle size distribution analysis. These properties were found depending to great extent on the nature of the precursors. The zirconia and ceria-stabilized zirconia obtained from adipate precursor were found to be good for slipcasting. The slips (i.e., suspensions) of these oxides with different solid contents were prepared at different $\mathrm{pH}$ with distilled water and ethanol as dispersing agents, with and without deflocculant. The suspension rheological flow (i.e., variation of shear stress and viscosity with shear rate) was determined. The minimum viscosities were observed at $\mathrm{pH}=10.16$ for $\mathrm{ZrO}_{2-}$ water and $\mathrm{pH}=10.26$ for $12 \mathrm{Ce}-\mathrm{TZP}$-water system. The slip, green and sedimentation bulk density were measured.
\end{abstract}

Keywords: Oxides; Ceramics; Chemical Synthesis; Surface Properties

\section{INTRODUCTION}

Zirconia and zirconia-base ceramics are of both scientific and technological interest as structural and func- tional materials due to their superior properties [1]. These powders have attracted much interest recently due to their specific optical and electrical properties [2-5] and potential applications [6-11]. Zirconia has three polymorphs: monoclinic, tetragonal and cubic [1]. The former is the thermodynamically stable and the other two are metastable polymorphs.

The addition of 'stabilizing' oxides, like $\mathrm{CaO}, \mathrm{MgO}$, $\mathrm{CeO}_{2}, \mathrm{Y}_{2} \mathrm{O}_{3}$ to pure zirconia allows to generate multiphase materials known as partially stabilized zirconia, whose microstructure at room temperature generally consists of cubic zirconia as the major phase, with monoclinic and tetragonal zirconia precipitated as the minor phase [12]. The improvement in the mechanical strength and toughness due to phase transformation in partially stabilized zirconia was first reported by Garvie et al. [13].

During the last decades an active research has been undertaken in different laboratories, in order to obtain zirconia and stabilized-zirconia powders with the required characteristics of size, purity, uniformity, crystallinity etc. A variety of methods have recently been described for the preparation of $\mathrm{ZrO}_{2}$ and $\mathrm{CeO}_{2}-\mathrm{ZrO}_{2}$ for potential applications. These methods includes conventional methods like co-precipitation [14-20], citrate process [17], polymerized complex process [18-21], sol-gel [22], gel-combustion process [23,24], spray pyrolysis [25], hydrothermal [26], surfactant templating [27,28], ultrasound [29] and sonochemical [30] methods etc.

A strong effort has been directed to increase the overall efficiency of $\mathrm{CeO}_{2}-\mathrm{ZrO}_{2}$ in various applications. One of the keys to this success is the selection of appropriate preparation methods and composition (i.e., $\mathrm{Ce} / \mathrm{Zr}$ ratio), which in turn determine homogeneity at a molecular level and morphological properties. Considerable interest is being shown in tetragonal zirconia polycrystalline ceramics. Coyle et al. [31] were among the first researchers to study tetragonal zirconia produced using the $\mathrm{ZrO}_{2}-\mathrm{CeO}_{2}$ system. The presence of tetragonal phase is an essential condition for zirconia toughening besides 
hindering or interrupting crack propagation [32].

In all the above technological applications, the control of rheology is of paramount importance for zirconia and partially stabilized zirconia [33-35], especially when stabilization and milling processes are used [33,35,36]. The rheological characteristics of aqueous suspensions depends on several experimental parameters such as particle size and particle size distributions, solids volume fraction, $\mathrm{pH}$ of suspending media, type and amount of added dispersing agents [37-40]. Despite the good knowledge of stabilization mechanism $[41,42]$ and the methods to make a well dispersed and stable slip, there is no general process applicable for ceria stabilized $\mathrm{ZrO}_{2}$ powders.

In this work we have prepared zirconia and ceria-stabilized zirconia by dicarboxylate precursor method. This method offers several advantages for processing ceramic powders such as direct and precise control of stoichiometry, uniform mixing of multicomponents on a molecular scale, and homogeneity. This method is also applied to synthesize ceria-stabilized zirconia showing to be effective to prepare zirconia with a tetragonal structure. In addition, the rheology of zirconia and ceria-stabilized zirconia is investigated in order to find out a suitable stabilization method. Several critical factors related to the slip rheology are studied, such as the influence of the amount of dispersant, and $\mathrm{pH}$ on viscosity of concentrated aqueous and nonaqueous slips. Finally, the density of green cast samples is studied and related to the degree of slip dispersion.

\section{EXPERIMENTAL PROCEDURE}

\subsection{Synthesis of Zirconyl Dicarboxylate Precursors}

(a) Zirconyl fumarate dihydrate, $\mathrm{ZrO}\left(\mathrm{C}_{4} \mathrm{H}_{2} \mathrm{O}_{4}\right) \cdot 2 \mathrm{H}_{2} \mathrm{O}$ was prepared by the precipitation method by taking high purity $\mathrm{ZrO}\left(\mathrm{NO}_{3}\right)_{2} \cdot \mathrm{nH}_{2} \mathrm{O}$ (9.989 gm) in deionized water $(100 \mathrm{ml})$ in a beaker. The $\mathrm{pH}$ of the medium was adjusted to a low enough value $(\mathrm{pH} \leq 6)$, so that hydroxide precipitate does not form. The solution was stirred vigorously with a magnetic stirrer. To this fumaric acid $(0.15 \mathrm{M})$ solution was then added slowly with stirring till a permanent precipitate occurred (precaution: don't add excess dicarboxylate). Acetone was added in equal amounts to metal salts to get more homogenous, stoichiometric, fine grained powders. The resultant precipitate of $\mathrm{ZrO}\left(\mathrm{C}_{4} \mathrm{H}_{2} \mathrm{O}_{4}\right) \cdot 2 \mathrm{H}_{2} \mathrm{O}$ was white in colour. The solution was filtered after stirring it for 30 minutes. The filtrate was checked for $\mathrm{Zr}^{4+}$ whose absence ensured complete precipitation. The precipitate was washed several times with cold distilled water and then with acetone to speed up the drying. It was air dried at the ambient temperature.

The similar experimental conditions were used for the preparation of other dicarboxylates such as (b) succinate, $\left(\mathrm{ZrO}\left(\mathrm{C}_{4} \mathrm{H}_{4} \mathrm{O}_{4}\right) \cdot 2 \mathrm{H}_{2} \mathrm{O}\right)$; (c) tartarate, $\left(\mathrm{ZrO}\left(\mathrm{C}_{4} \mathrm{H}_{4} \mathrm{O}_{6}\right) \cdot 2 \mathrm{H}_{2} \mathrm{O}\right)$; and $(\mathrm{d})$ adipate, $\left(\mathrm{ZrO}\left(\mathrm{C}_{6} \mathrm{H}_{8} \mathrm{O}_{4}\right) \cdot 2 \mathrm{H}_{2} \mathrm{O}\right)$.

\subsection{Synthesis of Ceria Doped Zirconyl Dicarboxylate Precursors}

(a) Ceria doped zirconyl fumarate one and half hydrate, $\mathrm{Ce}_{0.12} \mathrm{Zr}_{0.88} \mathrm{O}\left(\mathrm{C}_{4} \mathrm{H}_{2} \mathrm{O}_{4}\right) \cdot 1.5 \mathrm{H}_{2} \mathrm{O}$ was prepared according to the similar procedure described in above Subsection 2.1. by taking $\mathrm{Ce}\left(\mathrm{NO}_{3}\right)_{3} \cdot 6 \mathrm{H}_{2} \mathrm{O}$ (3.076 gm), $\mathrm{ZrO}\left(\mathrm{NO}_{3}\right)_{2} \cdot \mathrm{nH}_{2} \mathrm{O}$ (12.012 gm) in deionized water $(100 \mathrm{ml})$.

Other dicarboxylates such as (b) succinate, $\left(\mathrm{Ce}_{0.12}\right.$ $\left.\mathrm{Zr}_{0.88} \mathrm{O}\left(\mathrm{C}_{4} \mathrm{H}_{4} \mathrm{O}_{4}\right) \cdot \mathrm{H}_{2} \mathrm{O}\right)$; (c) tartarate, $\left(\mathrm{Ce}_{0.12} \mathrm{Zr}_{0.88} \mathrm{O}\left(\mathrm{C}_{4} \mathrm{H}_{4}\right.\right.$ $\left.\left.\mathrm{O}_{6}\right) \cdot 2 \mathrm{H}_{2} \mathrm{O}\right)$; and (d) adipate, $\left(\mathrm{Ce}_{0.12} \mathrm{Zr}_{0.88} \mathrm{O}\left(\mathrm{C}_{6} \mathrm{H}_{8} \mathrm{O}_{4}\right) \cdot \mathrm{H}_{2} \mathrm{O}\right)$ were prepared by following the procedure given above.

\subsection{Synthesis of Zirconia and Ceria-Stabilized Zirconia}

For the synthesis of zirconia and ceria-stabilized zirconia, the above dicarboxylate precipitates were decomposed and calcined slowly at $650^{\circ} \mathrm{C}$ for about $2 \mathrm{~h}$ in a platinum crucible under static air atmosphere and then slowly cooled $\left(3^{\circ} \mathrm{C} / \mathrm{min}\right)$ down to the room temperature. Thus the heat treatment is sufficient for achieving a complete decomposition of dicarboxylates. The powder obtained was polycrystalline. This sample was then reground and recalcined at the same temperature for another $2 \mathrm{~h}$. The furnace was turned off and sample was removed at room temperature. The obtained samples of zirconia and ceriastabilized zirconia were stored in a desiccator.

\subsection{Sample Characterization}

The elemental analysis of carbon and hydrogen were done by microanalytical technique. The metal analysis of the samples was carried out by Atomic absorption spectrometer (AAS) and Energy dispersive X-ray analysis (EDAX). The infrared spectra of precursor were recorded in the region $4000-450 \mathrm{~cm}^{-1}$ on the Perkin-Elmer - 1600 series FTIR spectrophotometer using KBr pellets. The TGA, DTG and DTA were recorded on Mettler Toledo 850 instrument.

The X-ray powder diffraction patterns were determined on Rigaku Miniflex Diffractometer using $\mathrm{CuK}_{\alpha}$ radiation $(\lambda=1.5405 \AA$; nickel filter). The BET surface area was determined from $\mathrm{N}_{2}$ adsorption isotherms using a Coulter (Omnisorp $100 \mathrm{CX}$ ) instrument. Morphological studies were carried out using scanning electron microscope (SEM) Philips 30XL model. The particle size distribution analysis was done using a dynamic light scattering method (Ultrafine Particle Analyzer (UPA) from Leeds and Northrup instrument). 


\subsection{Slip Preparation and Characterization}

For studying suspension rheological flow characteristics of oxide powders, several suspensions were prepared at conditions where they could be cast. Rheological tests permit to identify the conditions where the suspensions are better dispersed. For these tests, zirconia and ceriastabilized zirconia suspensions were prepared in water and ethanol with different solid loading, by using two different deflocculants such as Darvan (i.e. polymethcrylic acid) and M2OC (i.e. ammonium polyacrylate), by varying their concentrations and by varying the $\mathrm{pH}$ of the suspension.

The suspensions were placed in a polyethylene bottle with alumina balls and milled for $24 \mathrm{~h}$ to achieve good homogenous dispersion. After dispersing, the suspensions were degassed for several minutes under a rotary vacuum pump. Elico $\mathrm{pH}$-meter with a glass combination electrode was used to measure the $\mathrm{pH}$ in all suspension (i.e. slip). Hydrochloric acid $(\mathrm{HCl})$ and tetramethyl ammonium hydroxide $\left(\mathrm{C}_{4} \mathrm{H}_{13} \mathrm{NO}\right)$ solutions were used to adjust the suspension $\mathrm{pH}$. Suspension rheological flow characteristics (i.e. variation of shear stress and viscosity with shear rate) were determined with Brookfield viscometer model RVT with small sample adaptor accessory SC4 - 14/6R.

The degree of dispersion stability in the ceramic slurries was determined by measuring slip and sedimentation bulk density. For measuring the slip density, the suspension was poured in $5 \mathrm{ml}$ specific gravity bottle and suspension weight was measured. Sedimentation bulk density was determined by pouring the suspension i.e. slip (of known weight) into $5 \mathrm{ml}$ measuring cylinder. The measuring cylinder was covered with flexible film (to prevent solvent evaporation) and the particles in suspension were allowed to settle until the sediment height no longer changed with time. The sedimentation bulk volume was determined directly from sedimentation height in the measuring cylinder. The weight of $\mathrm{ZrO}_{2}$ or ceria-stabilized $\mathrm{ZrO}_{2}$ in the sedimentation volume was determined by multiplying the known weight of suspension in the cylinder times the known weight percentage of $\mathrm{ZrO}_{2}$ or ceria-stabilized $\mathrm{ZrO}_{2}$ in the suspension.

The suspension was then cast in a $20 \mathrm{~mm} \times 20 \mathrm{~mm} \times 10$ $\mathrm{mm}$ acrylate mould placed on a plaster of Paris bricks. After $2 \mathrm{~h}$, the cast solid (i.e. green body) was removed from the mould. The obtained green bodies were dried at room temperature for one day, and then at $110^{\circ} \mathrm{C}$ for one day.

For measuring the percent shrinkage, the dimension of the green bodies dried at room temperature was measured using the Vernier caliper. The green bodies were then dried at $110^{\circ} \mathrm{C}$ for one day in electric oven. After drying again the dimension of the green bodies was measured. The green density of the samples was meas- ured using Archimedes method. Before determination of the weight in water, the green bodies were immersed in paraffin to close the pores.

\section{RESULTS AND DISCUSSION}

\subsection{Dicarboxylate Coprecipitation}

During synthesis, several parameters which may influence the amount of zirconyl dicarboxylate precipitates at $25^{\circ} \mathrm{C}$. In order to reach required stoichiometry in dicarboxylate precipitates, the control $\mathrm{pH}$ and concentration of metal salt solution is very important.

1) Effect of zirconium concentration

A series of experiments has been made to determine the most appropriate zirconium concentration values for a maximum precipitation of dicarboxylates. Several dicarboxylates such as fumarate, succinate, tartarate and adipate have been prepared with the zirconium concentration ranging from 0.05 to $0.4 \mathrm{M}$. The maximum amount of zirconyl dicarboxylate precipitates ( $90 \%)$ are obtained for the zirconium content equals to $0.25 \mathrm{M}$.

2) Effect of dicarboxylate concentration

A second series of trials has been made to determine the most appropriate concentrations of dicarboxylic acids such as fumaric, succinic, tartaric and adipic acid. It is observed that in all cases the maximum $(\sim 92 \%)$ precipitation yield is obtained when dicarboxylic acid concentration is equals to $0.15 \mathrm{M}$. For more dicarboxylic acid concentration, it shows a decrease of zirconyl precipitation. Therefore to balance this concentration and to satisfy practical considerations, we use optimal concentration, i.e., $0.15 \mathrm{M}$ dicarboxylic acid is used for precipitation

In case of zirconyl dicarboxylates, the effect of $\mathrm{pH}$ could not studied, since for $\mathrm{pH}$ adjustment, precipitation occur immediately by addition of $10 \% \mathrm{NH}_{4} \mathrm{OH}$. So the $\mathrm{pH}$ and dicarboxylic acid concentration have been chosen so that the solubility of zirconyl dicarboxylates is as low as possible. It is difficult to give an exact figure for new solubility values for dicarboxylate precipitate. The best range of $\mathrm{pH} \approx 4.5$ to 6.0 is used for the synthesis of zirconyl dicarboxylate (i.e. precursor).

\subsection{Characterization of Dicarboxylate Precursors}

The composition of precursor is characterized at first stage by elemental analysis and Atomic absorption spectrometry (AAS). The elemental analysis of dicarboxylate precursors were made in wt.\%: for fumarate, $\mathrm{ZrO}\left(\mathrm{C}_{4} \mathrm{H}_{2}\right.$ $\left.\mathrm{O}_{4}\right) \cdot 2 \mathrm{H}_{2} \mathrm{O}(\mathrm{C}, 18.83$ (18.67); H, 2.22 (2.33); Zr, 35.86 (35.45)) and $\mathrm{Ce}_{0.12} \mathrm{Zr}_{0.88} \mathrm{O}\left(\mathrm{C}_{4} \mathrm{H}_{2} \mathrm{O}_{4}\right) \cdot 1.5 \mathrm{H}_{2} \mathrm{O}(\mathrm{C}, 18.32$ (18.90); H, 2.06 (1.96); Zr, 31.60 (31.57); Ce, 6.51 (6.61)). For succinate, $\mathrm{ZrO}\left(\mathrm{C}_{4} \mathrm{H}_{4} \mathrm{O}_{4}\right) \cdot 2 \mathrm{H}_{2} \mathrm{O}(\mathrm{C}, 18.67$ 
(18.52); H, $2.54 \quad(3.08) ; \quad \mathrm{Zr}, \quad 35.19 \quad(35.18))$ and $\mathrm{Ce}_{0.12} \mathrm{Zr}_{0.88} \mathrm{O}\left(\mathrm{C}_{4} \mathrm{H}_{4} \mathrm{O}_{4}\right) \cdot \mathrm{H}_{2} \mathrm{O}(\mathrm{C}, 19.53$ (19.43); H, 2.65 (2.42); $\mathrm{Zr}, 32.55$ (32.47); Ce, 6.93 (6.80)). For tartarate, $\mathrm{ZrO}\left(\mathrm{C}_{4} \mathrm{H}_{4} \mathrm{O}_{6}\right) \cdot 2 \mathrm{H}_{2} \mathrm{O}(\mathrm{C}, 16.65$ (16.49); H, 2.84 (2.74); $\mathrm{Zr}, 31.18$ (31. 31)) and $\mathrm{Ce}_{0.12} \mathrm{Zr}_{0.88} \mathrm{O}\left(\mathrm{C}_{4} \mathrm{H}_{4} \mathrm{O}_{6}\right) \cdot 2 \mathrm{H}_{2} \mathrm{O}(\mathrm{C}$, 16.45 (16.17); H, 3.01 (2.69); Zr, 27.16 (27.00); Ce, 5.73 (5.65)). For adipate, $\mathrm{ZrO}\left(\mathrm{C}_{6} \mathrm{H}_{8} \mathrm{O}_{4}\right) \cdot 2 \mathrm{H}_{2} \mathrm{O} \quad(\mathrm{C}, 24.81$ (25.07); $\mathrm{H}, 3.71$ (4.17); $\mathrm{Zr}, 31.95$ (31.74)) and $\mathrm{Ce}_{0.12} \mathrm{Zr}_{0.88} \mathrm{O}\left(\mathrm{C}_{6} \mathrm{H}_{8} \mathrm{O}_{4}\right) \cdot \mathrm{H}_{2} \mathrm{O}$ (C, 26.24 (26.16); H, 3.12 (3.63); $\mathrm{Zr}, 29.18$ (29.15); Ce, 6.07 (6.11)). The values in the parenthesis are calculated ones. The observed values are found to be $\pm 0.5 \%$ of the nominated values.

The energy dispersive X-ray analysis (EDAX) further confirms all the cations were present in a perfect cationic ratio in the precursor. The peaks pertaining to all the cations were present in the EDAX spectrum. The elemental composition analysis at several spots was uniform, which is indicative of a highly homogeneous material. This is due to the fact that all the cations are uniformly mixed.

The presence of water of crystallization for these precursors was confirmed on the basis of the thermal analysis curves under static air atmosphere. These results are further supplemented by infrared spectroscopic measurements. The bidentate linkage of dicarboxylate group with metal was confirmed on the basis of the difference between the antisymmetric and symmetric stretching frequencies. A chain like polymeric octahedral structure has been assigned by infrared spectra for these precursors.

Thermal analysis (TGA, DTG and DTA) of the precursors shows that all the complexes dehydrate and decompose in the temperature range $30-600^{\circ} \mathrm{C}$. It is observed that the weight loss in TGA corresponds to the formation of respective zirconia or ceria-stabilized zirconia.

\subsection{Characterization of Zirconia and Ceria-stabilized Zirconia}

After characterizing the above precursor was decomposed slowly at $650^{\circ} \mathrm{C}$ to form respective oxides. The
X-ray diffraction (XRD) patterns of zirconia obtained from all precursors shows the tetragonal phase. The experimentally observed d-spacing values and relative intensities are compared with those reported in the literature [43]. The lattice parameters for each compound are calculated and are listed in Table $\mathbf{1}$.

Similarly the addition of $3,6,9,12$ mol.\% of ceria to the system, allows stabilization of zirconia matrix in tetragonal phase. It is observed that for 3 to $9 \mathrm{~mol} . \%$ ceria in $\mathrm{ZrO}_{2}$, the diffraction peak to XRD spectra reveal that the material crystallizes in face centered cubic fluorite type structure. However, for $12 \mathrm{~mol} \%$ ceria in $\mathrm{ZrO}_{2}$ powder, the diffraction lines are matched to the tetragonal phase, on the other hand above $12 \mathrm{~mol} \%$ ceria the tetragonal phase is collapse. Thus $12 \mathrm{~mol} . \%$ ceria stabilized $\mathrm{ZrO}_{2}$ retained tetragonal phase at room temperature. The experimentally observed d-spacing values and relative intensities are compared with those reported in the literature [43]. The lattice parameter for $12 \mathrm{~mol} \%$ ceria stabilized zirconia prepared from different dicarboxylate are then calculated and shown in Table $\mathbf{1}$.

The morphology of ceria-stabilized $\mathrm{ZrO}_{2}$ powders was also analyzed by scanning electron micrographs (SEM), which revealed agglomerates with irregular shape and variable packing density of their primary particles (Figure 1). According to literature [44], these agglomerates can be classified as 'soft' or 'hard', the hard agglomerates consisting of close-packed particles with high densities. As can be seen from Figures 1(a) and (b), the 3 and $6 \mathrm{~mol} \%$ ceria stabilized zirconia shows agglomerated structures, while $9 \mathrm{~mol} \%$ ceria content zirconia show fused agglomerates (Figure 1(c)). However, for $12 \mathrm{~mol} \%$ ceria content zirconia, the SEM show less dense agglomerates, suggesting soft agglomerates with particles connected by Van der Waals forces. Thus increasing ceria content, the concentration of intra-aggregate pore are decreased meaning a reduction of the aggregates content, up to the disappearance for powder containing $12 \mathrm{~mol} . \% \mathrm{CeO}_{2}$.

The common notation used in tetragonal zirconia

Table 1. X-ray Powder diffraction and particulate properties data of zirconia and ceria-stabilized zirconia powders.

\begin{tabular}{|c|c|c|c|c|c|}
\hline \multirow{2}{*}{ Compound } & \multicolumn{2}{|c|}{ Lattice Parameters (nm) } & Mean Grain size & \multirow{2}{*}{$\begin{array}{c}\text { Surface Area } \\
\mathrm{m}^{2} / \mathrm{g}\end{array}$} & \multirow{2}{*}{ Average particle size (by SEM) nm } \\
\hline & $\mathrm{a}_{0}$ & $\mathrm{c}_{0}$ & $<\mathrm{D}>_{\text {Xray }} \quad \mathrm{nm} \pm 10 \%$ & & \\
\hline \multicolumn{6}{|c|}{ (a) zirconia } \\
\hline Fumarate & 0.511 & 0.518 & 21.03 & 4.87 & 900 \\
\hline Succinate & 0.510 & 0.519 & 22.37 & 1.00 & 427 \\
\hline Tartarate & 0.510 & 0.519 & 22.11 & 1.83 & 569 \\
\hline Adipate & 0.511 & 0.518 & 16.77 & 7.26 & 222 \\
\hline \multicolumn{6}{|c|}{ (b) ceria-stabilized zirconia } \\
\hline Fumarate & 0.509 & 0.513 & 18.03 & 10.33 & 178 \\
\hline Succinate & 0.507 & 0.511 & 19.24 & 12.88 & 357 \\
\hline Tartarate & 0.510 & 0.513 & 14.35 & 11.26 & 476 \\
\hline Adipate & 0.507 & 0.512 & 13.46 & 10.55 & 264 \\
\hline
\end{tabular}




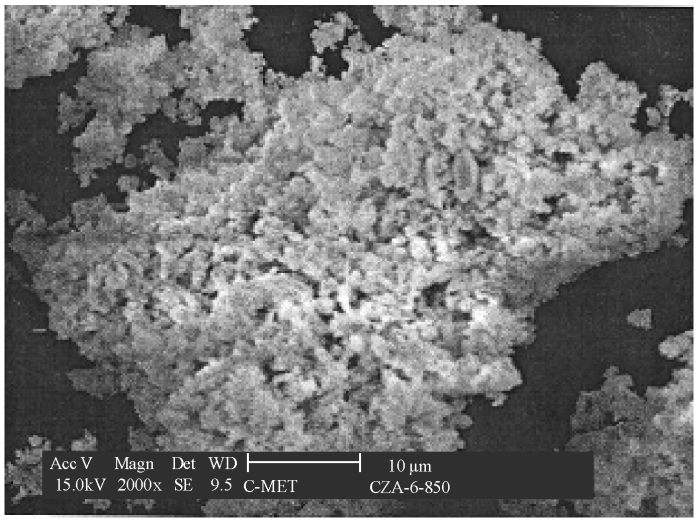

(a)

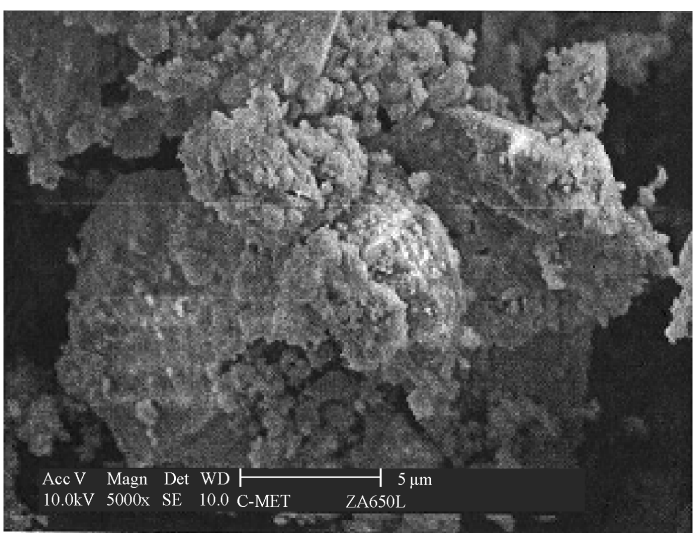

(c)

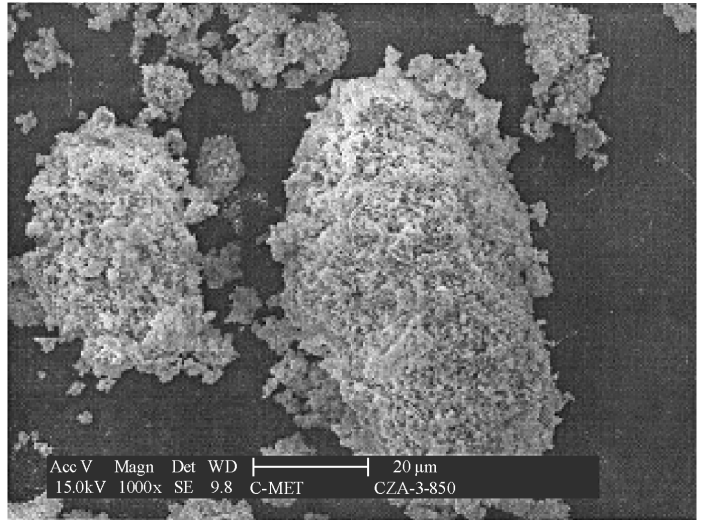

(b)

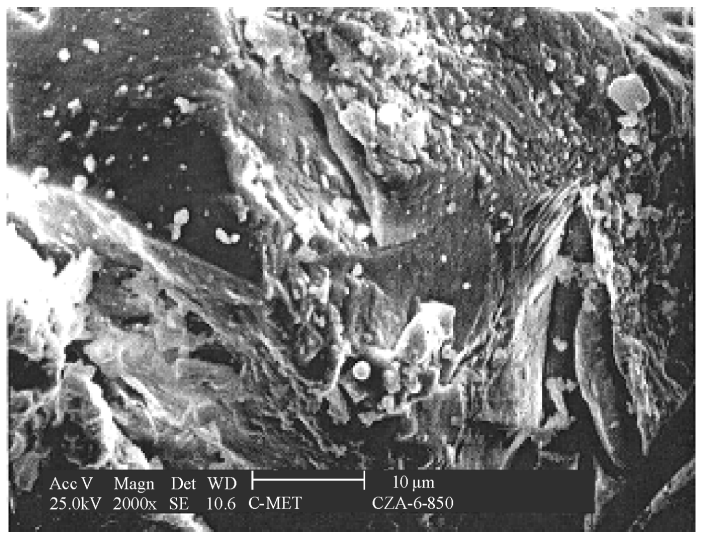

(d)

Figure 1. Scanning electron micrographs (SEM) of zirconia powders containing: (a) 3 mol.\% ceria; (b) 6 mol.\% ceria; (c) 9 mol.\% ceria and (d) 12 mol.\% ceria.

polycrystal (TZP), literature [45] involves placing the cation symbol of the stabilizing oxide before the TZP abbreviation. In some cases the molarity of the stabilizing oxide will be indicated by a number before the cation symbol e.g.

$$
\mathrm{ZrO}_{2}-12 \text { mol. } \% \mathrm{CeO}_{2}=12 \mathrm{Ce}-\mathrm{TZP} \text {. }
$$

The mean grain sizes of $\mathrm{ZrO}_{2}$ and $12 \mathrm{Ce}-\mathrm{TZP}$ are also calculated from Debye-Scherrer equation [46]. The observed mean grain size $\langle\mathrm{D}\rangle_{\mathrm{X} \text {-ray }}$ for $\mathrm{ZrO}_{2}$ and $12 \mathrm{Ce}-\mathrm{TZP}$ compounds are respectively in the range of 16.77 to $22.36 \mathrm{~nm}$, and 13.46 to $19.24 \mathrm{~nm}$ (Table 1). The BET specific surface areas are also listed in Table 1. Under the experimental conditions, the $\mathrm{CeO}_{2}$ content affected both grain size and surface area of the powders. As observed in Table 1, the grain size decreases with the increase of $\mathrm{CeO}_{2}$ content, i.e., grain growth of zirconia is inhibited by the ceria doping in zirconia. It is interesting to observe here that, surface areas increased with a increase of $\mathrm{CeO}_{2}$ content because of the crystallite coarsening. This suggests that increasing ceria content reduces the surface free energy of zirconia particles and so increases the surface area, which is accompanied by more effective tetragonal phase stabilization.

Figure 2 shows scanning electron micrographs (SEM) of $\mathrm{ZrO}_{2}$ and $12 \mathrm{Ce}-\mathrm{TZP}$ powders obtained from fumarate, succinate, tartarate and adipate precursors at $650^{\circ} \mathrm{C}$. The $\mathrm{ZrO}_{2}$ powder obtained from fumarate precursor shows higher degree of agglomerations, whereas $\mathrm{ZrO}_{2}$ obtained from tartarate shows apparent agglomeration of very fine particles (Figure 2(a)). Highly irregular shaped large particles are observed in case of $\mathrm{ZrO}_{2}$ obtained from succinate. Moderate sized particles with less agglomeration are observed in $\mathrm{ZrO}_{2}$ obtained from adipate. The average particle size for all $\mathrm{ZrO}_{2}$ powders is in the range of 222 to $900 \mathrm{~nm}$.

All 12Ce-TZP powders show less agglomerated structures as compared to $\mathrm{ZrO}_{2}$ powders (Figure 2(b)). Among these powders the 12Ce-TZP obtained from adipate precursor shows moderate size less agglomerated particles than $12 \mathrm{Ce}-\mathrm{TZP}$ obtained from fumarate, succinate and tartarate precursor. The average particle sizes of $12 \mathrm{Ce}-\mathrm{TZP}$ powders obtained from different dicarboxylates are in the range of 178 to $476 \mathrm{~nm}$. 


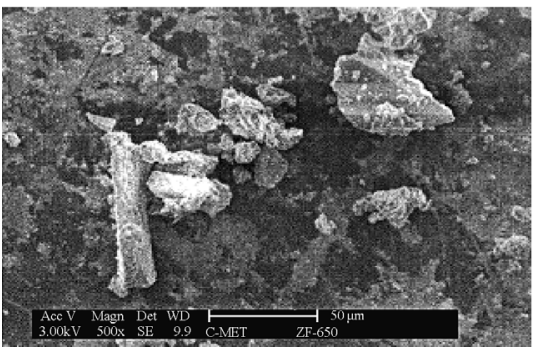

Fumarate

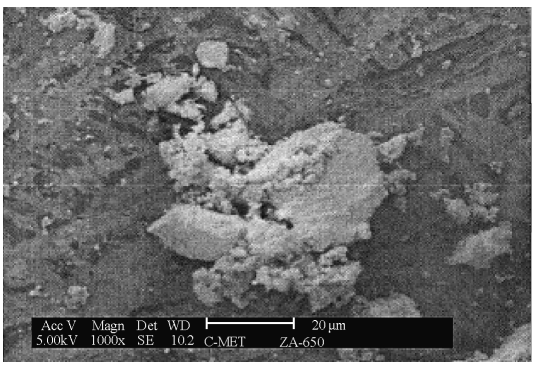

Tartarate

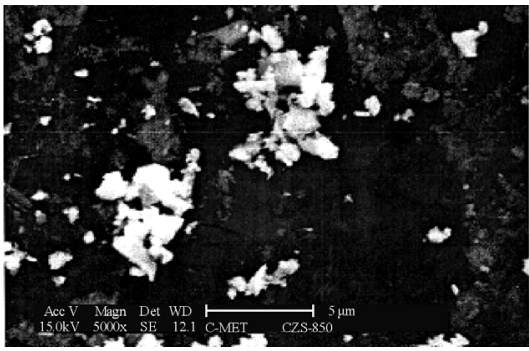

Fumarate

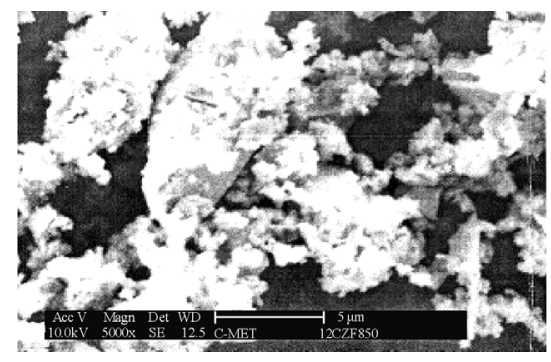

Tartarate

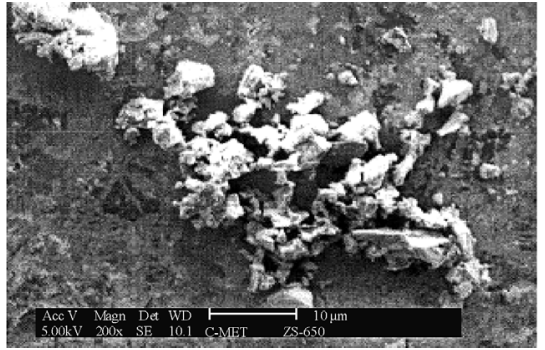

Succinate

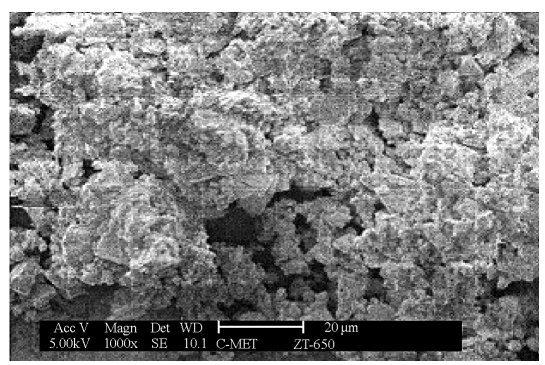

Adipate

(a)

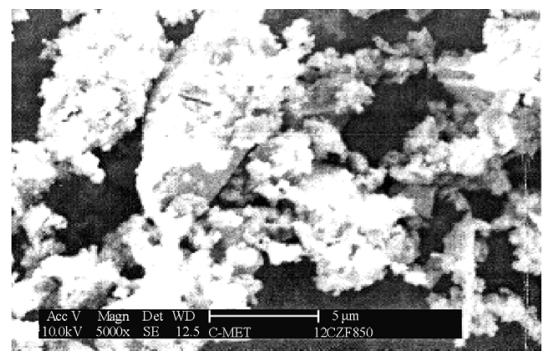

Succinate

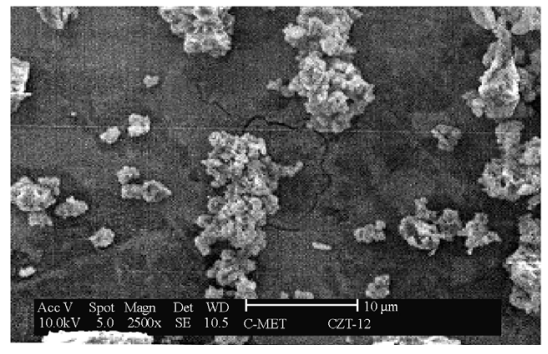

Adipate

(b)

Figure 2. Scanning electron micrographs (SEM) of (a) zirconia $\left(\mathrm{ZrO}_{2}\right)$ (b) ceria-stabiized zirconia (12 Ce-TZP) powders obtained from different dicarboxylate precursors.

\subsection{Rheological Studies}

\subsubsection{Powder Characteristics}

Particle size distribution was measured using laser based particle size analyzer. The preliminary experiments indicated that distilled water and ethanol could be used to disperse the powder. Figure 3 displays the particle size distribution of $\mathrm{ZrO}_{2}$ and $12 \mathrm{Ce}-\mathrm{TZP}$ powders obtained from different dicarboxylates. From the particle size distribution measurements occurred that the powder ex- hibits a wide size distribution and $90 \%$ powder being below $2.5 \mu \mathrm{m}$ for $\mathrm{ZrO}_{2}$ and $0.9 \mu \mathrm{m}$ for 12Ce-TZP (Figures 3(a) and (b)). The particle size distribution of $\mathrm{ZrO}_{2}$ obtained from adipate precursor show 30 to $40 \%$ particles below $1.6 \mu \mathrm{m}$ and remaining particle have above 1.6 $\mu \mathrm{m}$. While, $12 \mathrm{Ce}-\mathrm{TZP}$ powders shows 30 to $40 \%$ particles of $0.4 \mu \mathrm{m}$ range and remaining have above $0.4 \mu \mathrm{m}$. Thus bimodal type of particle distribution is observed in both the oxides obtained from adipate precursor. The 


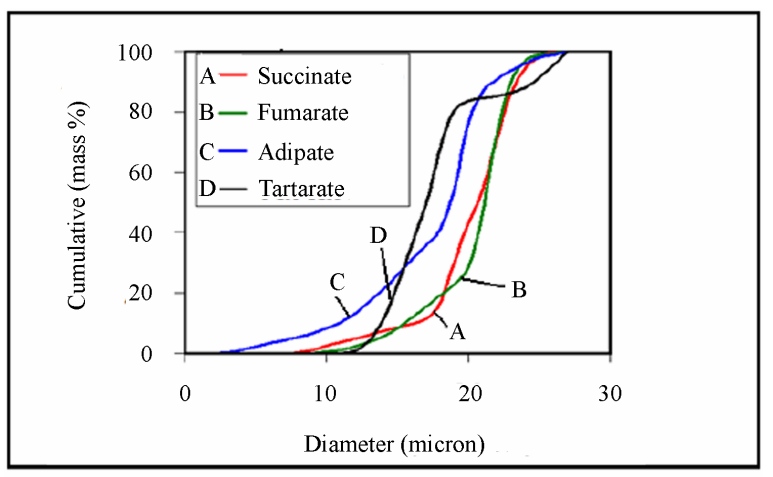

(a)

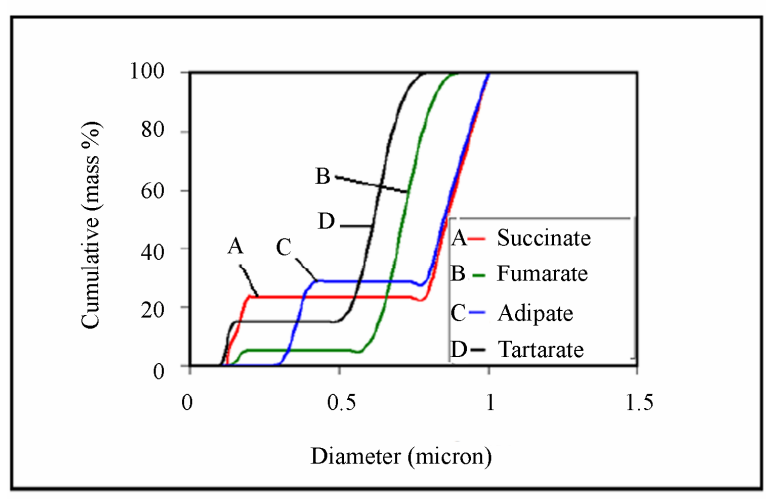

(b)

Figure 3. Particle size distribution analysis of (a) zirconia $\mathrm{ZrO}_{2}$ and (b) ceria stabilized zirconia $12 \mathrm{Ce}-\mathrm{TZP}$ powders obtained from different dicarboxylate precursors.

particle packing is based on the concept of filling the voids in a bed of large spheres with smaller sized spheres. The remaining pores between the smaller spheres are then filled with still smaller spheres, etc. to give good particle packing [47]. The particle size distribution of $\mathrm{ZrO}_{2}$ and $12 \mathrm{Ce}-\mathrm{TZP}$ powders obtained from fumarate, succinate and tartarate shows either smaller or larger particles (Figure 3). Thus $\mathrm{ZrO}_{2}$ and $12 \mathrm{Ce}-\mathrm{TZP}$ obtained from adipate are considered to be good for slip-casting and hence we prepared in large quantity ( 200 gm).

\subsubsection{Optimization of Rheological Properties of Slurries}

The state of particulate dispersion is affected mainly by particle size and particle size distribution, specific surface area of powder and on chemistry of solid/liquid interface [48], dispersion mechanism [49], and so on. The viscosity of the suspensions increases drastically and abruptly, when the weight percent of solid in the suspension is increased beyond a critical value.

1) Effects of solid loading

The present study shows the viscosity versus shear rate (Figure 4) for aqueous (distilled water) and nonaqueous (ethanol), $\mathrm{ZrO}_{2}$ and $12 \mathrm{Ce}-\mathrm{TZP}$ (obtained from adipate precursor) suspensions prepared with various solid loadings (solid/liquid ratios of 75/25, 80/20 and $70 / 30$ by weight and $1.0 \mathrm{wt} \% \%$ M20C deflocculant). It can be seen that the aqueous and non-aqueous suspensions with $80 \mathrm{wt} . \%$ maximum loading can be achieved a low viscosity for $\mathrm{ZrO}_{2}$ powder, while $75 \mathrm{wt} . \%$ maximum solid loading can be seen the suspension exhibit low viscosity for $12 \mathrm{Ce}-\mathrm{TZP}$ powder. Above these weight percent, the suspension has a high viscosity and pseudoplastic behavior.

2) Effect of dispersant concentration

In the present study, Darvan and M20C are used as a dispersants (sometimes called deflocculants). The viscosity versus shear rate curves of the suspensions with constant solid loading ( $80 \mathrm{wt} . \% \mathrm{ZrO}_{2}$ and $75 \mathrm{wt} . \% 12 \mathrm{Ce}-\mathrm{TZP}$ ) in the presence of different added amounts of Darvan and M20C dispersants are presented in Figures 5 and $\mathbf{6}$ respectively. From the plots, an optimum Darvan concentration with $1 \mathrm{wt} \%$ for $\mathrm{ZrO}_{2}$-water and ethanol system and $0.8 \mathrm{wt} \%$ for $12 \mathrm{Ce}-\mathrm{TZP}$-water and ethanol system could be determined to be minimum viscosity (Fig-

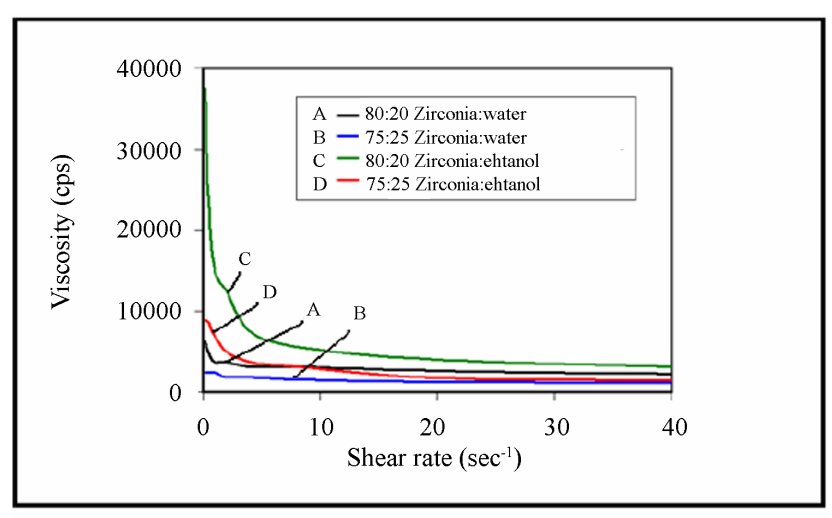

(a)

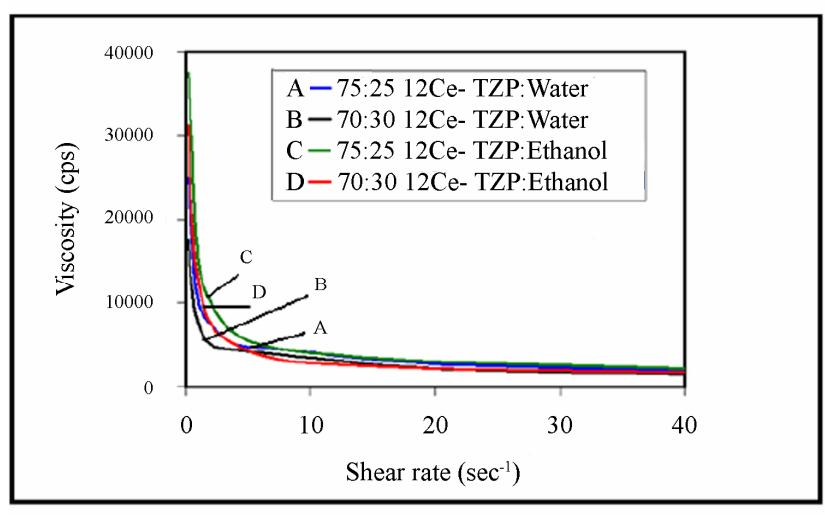

(b)

Figure 4. Plots of viscosity against shear rate with different percentage solid loading. (a) zirconia and (b) $12 \mathrm{Ce}-\mathrm{TZP}$ powders in water and ethanol system. 
ure 5). Similarly, in the presence of M20C dispersant, the optimum concentration with $1.2 \mathrm{wt} \%$ for $\mathrm{ZrO}_{2}$-water and ethanol system and $1.0 \mathrm{wt} \%$ for $12 \mathrm{Ce}-\mathrm{TZP}$-water and ethanol, the suspension exhibits nearly constant viscosity and could be fitted to Newtonian flow behavior (Figure 6). With further increasing the amount of dispersant, the suspensions show pseudoplastic behavior and the viscosity level also increases. It is interesting to observe that the $\mathrm{M} 20 \mathrm{C}$ is the best dispersant, which show minimum value of viscosity than Darvan dispersant. Similarly, slurries prepared in distilled water along with M20C dispersant show low viscosity than slurries prepared in ethanol medium. Thus, distilled water and M20C dispersant are used for rheological studies for $\mathrm{ZrO}_{2}$ and $12 \mathrm{Ce}-\mathrm{TZP}$ powders.

In above two cases, with low solid loading, the mag-nitude of the average Van der Waals forces could be small due to the relatively large distance between suspended particles, so a small addition of dispersant could lead to repulsion forces with enough magnitude to counterbalance Van der Waals forces [50], and the frequency of the collisions between separated particles is lower.

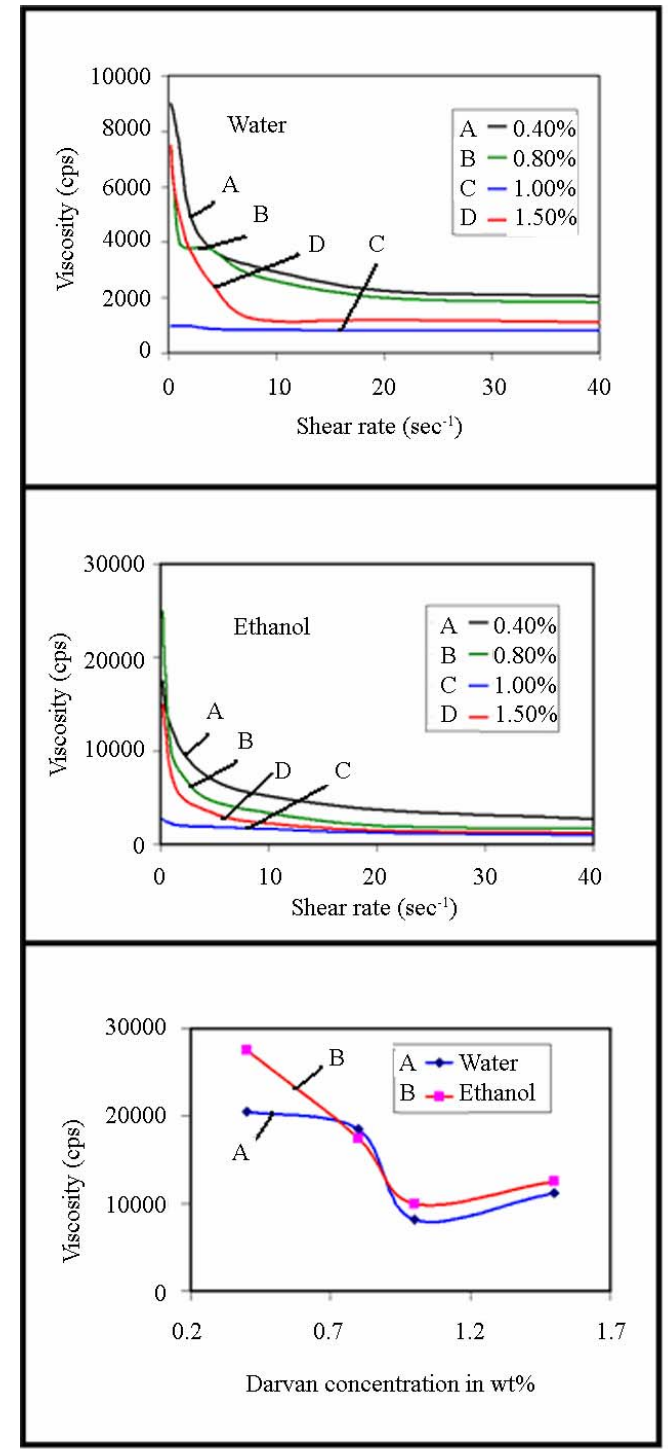

(a)

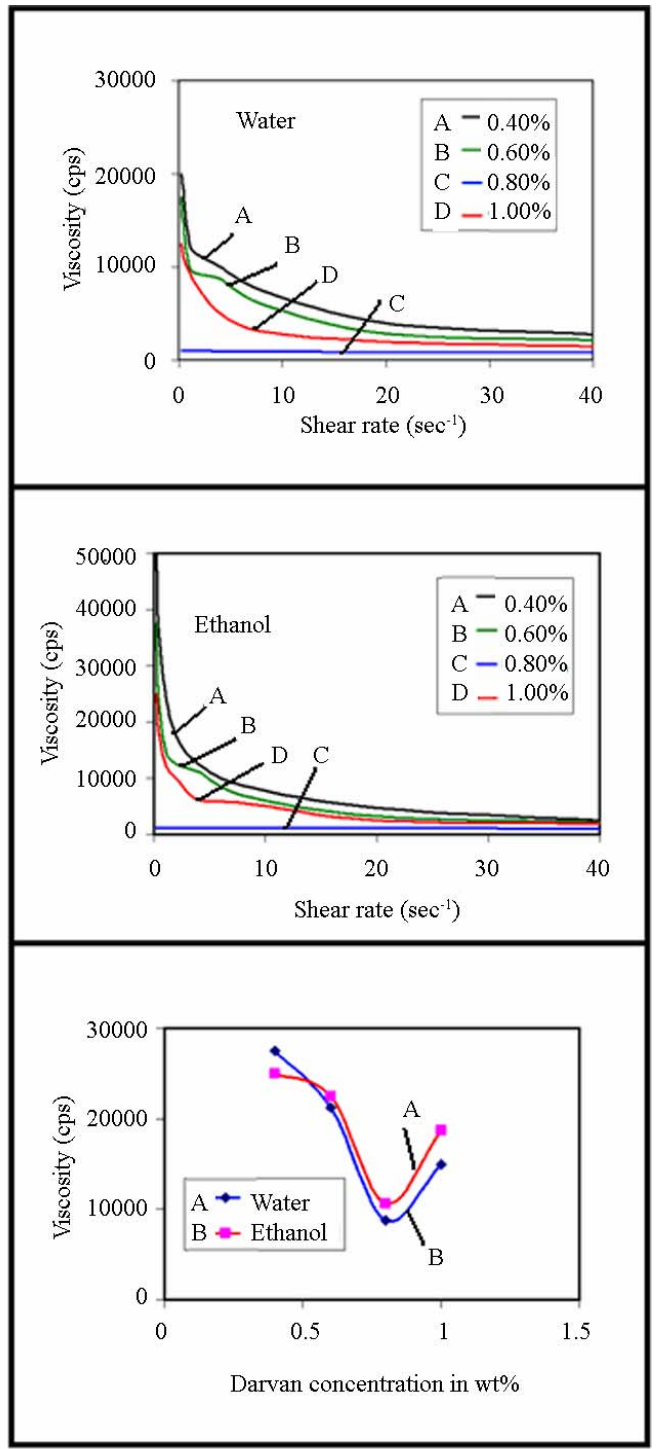

(b)

Figure 5. Plots of viscosity against shear rate for different concentration of Darvan deflocculant (dispersant) in water and ethanol system and plots of viscosity against Darvan concentration (at constant shear rate of 40 $\sec ^{-1}$ ). (a) $\mathrm{ZrO}_{2}$; (b) $12 \mathrm{Ce}-\mathrm{TZP}$ powders. 


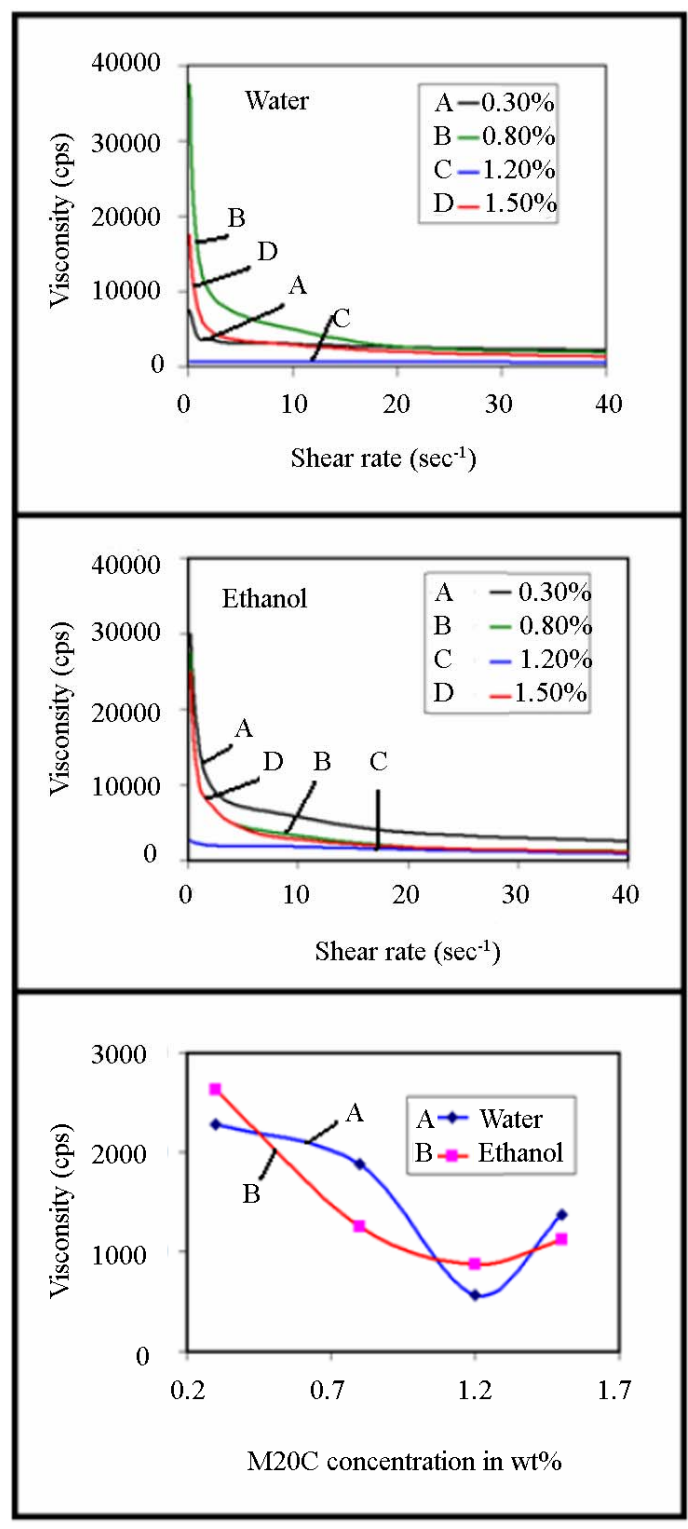

(a)

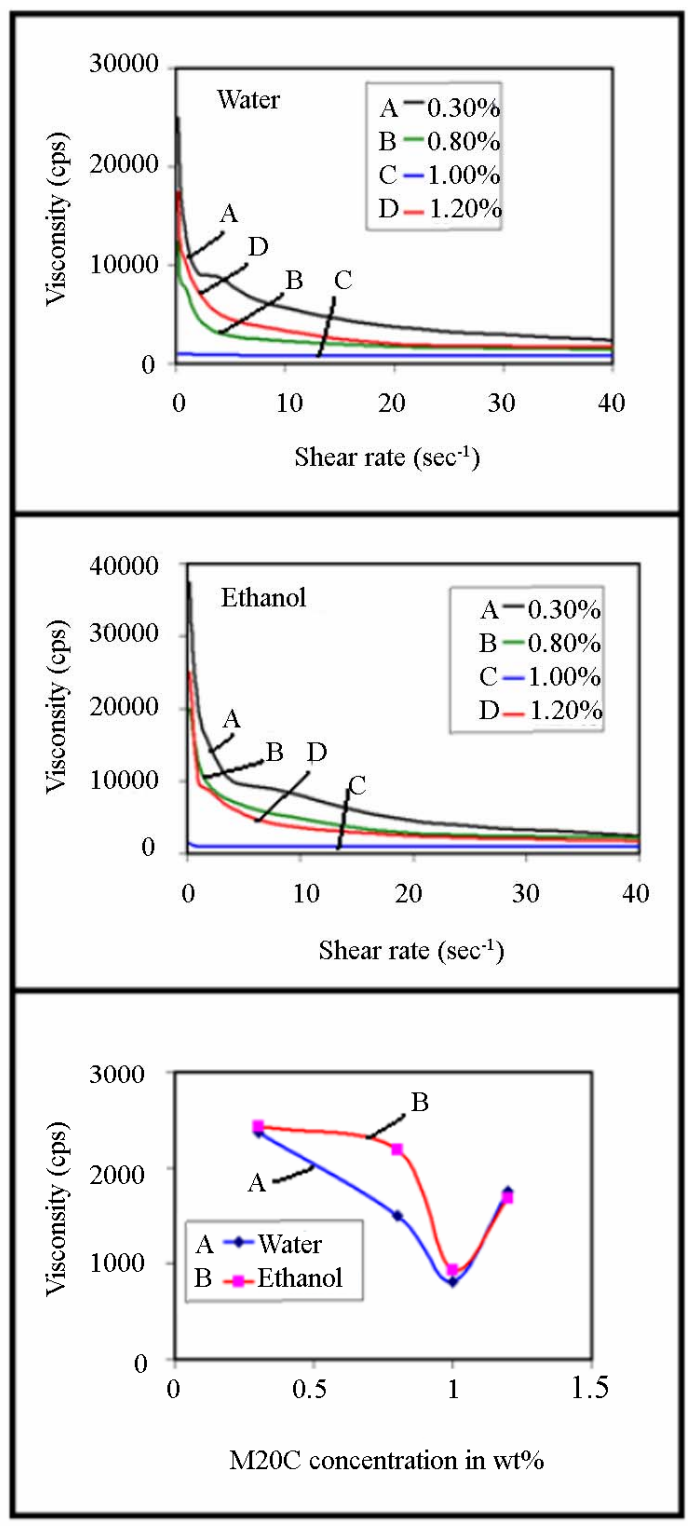

(b)

Figure 6. Plots of viscosity against shear rate for different concentration of M20C deflocculant (dispersant) in water and ethanol system and plots of viscosity against M20C concentration (at constant shear rate of $40 \mathrm{sec}^{-1}$ ). (a) $\mathrm{ZrO}_{2}$ (b) $12 \mathrm{Ce}-\mathrm{TZP}$ powders.

This explains why the rheological properties of the suspensions are almost unaffected by the amount of dispersant at low solids loading. However, it should also be pointed out that due to insufficient surface coverage at lower dispersant additions, the balance between Van der Waals forces and steric forces is not completely stable, and agglomerates would easily form through the uncovered surface sites due to Brownian motion. With increasing solid loading, the importance of Van der Waals forces also increases due to the shorter distances between suspended particles. Therefore, agglomerates will readily form if insufficient amount of dispersant is added, under which conditions Van der Waals forces will dominate the interaction between suspended particles, and significant shear thinning will be observed due to the breakdown of agglomerates because of the applied shear [51].

\subsubsection{Rheology of Slips}

One of the widely practiced methods to stabilize the slips is electrostatic stabilization, achieved by the repulsion of equally charged particles. The repulsive interac- 
tion results from the development of an electric double layer around the particles up on dispersing a powder into a aqueous (polar) media and is a function of $\mathrm{pH}$, the concentration of specifically adsorbed ions and the ionic strength of the suspension [52]. The repulsive force decreases with increasing separation between the particles. The possibility of electrostatic stabilization can be evaluated by measuring viscosity-shear rate as a function of $\mathrm{pH}$.

To study the rheological properties, the slips were prepared in the following way:

1) $80 \mathrm{wt} \% \mathrm{ZrO}_{2}$ and $20 \mathrm{wt} \%$ distilled water along with $1.2 \mathrm{wt} \% \mathrm{M} 20 \mathrm{C}$ dispersant.

2) $75 \mathrm{wt} \%$ 12Ce-TZP and $25 \mathrm{wt} \%$ distilled water along with $1.0 \mathrm{wt} \% \mathrm{M} 20 \mathrm{C}$ dispersant.

After homogeneous mixing of slips, the $\mathrm{pH}$ was adjusted to various levels by adding $\mathrm{HCl}$ or tetramethyl ammonium hydroxide. In slip-casting processing, the amount and rate of dissolution of ions is important [53]. The dissolution of $\mathrm{Zr}$ is lower than that of $\mathrm{Si}$ and is slightly reduced with increasing mixing time, i.e., above $110 \mathrm{~h}$ [42]. In other report [54], cerium dissolution rate of $\mathrm{Ce}-\mathrm{ZrO}_{2}$ powder under slightly acidic conditions $(\mathrm{pH}$ $=3$ to 5.5$)$, only small amounts $\left(1-2 \mathrm{mg} \mathrm{L}^{-1}\right.$ after $10 \mathrm{~h}$ stirring) of cerium were dissolved. No dissolution of cerium or zirconium was found under basic conditions. According to these literatures, in the present case the slurries were prepared by mechanical stirring at room temperature for $4 \mathrm{~h}$ before the viscosity measurements. Thus, the dissolution of $\mathrm{Zr}$ and $\mathrm{Ce}$ are totally negligible in our samples $\left(\mathrm{ZrO}_{2}\right.$ and $12 \mathrm{Ce}-\mathrm{TZP}$ powders $)$. The slurry stability was also evaluated by measuring the settling of powder (sedimentation height as a percentage of the total suspension height) for different $\mathrm{pH}$ of the slips. The viscosity behavior and sedimentation density are given in Table 2.
Figures 7(a) and (b) show the rheological behavior (i.e. viscosity-shear rate) at several $\mathrm{pH}$ values for $\mathrm{ZrO}_{2}-$ water and 12Ce-TZP-water systems, with M20C dispersant (i.e. deflocculant). The viscosity dependence of various $\mathrm{pH}$ values at constant shear rate $\left(\mathrm{D}=40 \mathrm{sec}^{-1}\right)$ are also shown in Figure 7. It is seen that, at neutral $\mathrm{pH}$ the viscosity shows a maximum value, while for acidic or basic range of $\mathrm{pH}$, the viscosity shows a minimum value. At these minimum viscosity values, the rheological behavior is Newtonian, i.e., viscosity is independent of shear rate. At this $\mathrm{pH}$ range, the particles are well dispersed and show high slip and sedimentation density. These results are also presented in Table 2. At remaining $\mathrm{pH}$ values, viscosity is high and slip has pseudoplastic behavior. Thus, the high sedimentation density and low viscosity values tend to form good green bodies. Usually, basic slips are preferred to prevent the rapid formation of strong bond between the contracted particulate suspension and mould during casting process [53]. On the other hand a high concentration of acid slips is corrosive and attacks the mould used for casting, which can cause contamination by dissolution of gypsum.

\subsubsection{Slip Casting}

The packing ability of the dispersed particles on the slip casting is a good index of the dispersion degree achieved in the suspensions, and was evaluated by pouring the required amounts of the slips into a plaster mould. The $\mathrm{ZrO}_{2}$ and $12 \mathrm{Ce}-\mathrm{TZP}$ slips obtained at different $\mathrm{pH}$ are then de-aired under a mild vaccum for $15 \mathrm{~min}$. These slips are then poured into a square plaster mould $(20 \mathrm{~mm}$ $\times 20 \mathrm{~mm} \times 10 \mathrm{~mm}$ ). The liquid is draw into pores by capillary action. After $2 \mathrm{~h}$ the rectangular green bodies were removed from the mould and dried at room temperature for $24 \mathrm{~h}$ and then put in an oven at $110^{\circ} \mathrm{C}$ for another $24 \mathrm{~h}$ period. The percent shrinkage was calcu-

Table 2. Rheological properties of $\mathrm{ZrO}_{2}$ and $12 \mathrm{Ce}-\mathrm{TZP}$ slips at several $\mathrm{pH}$ values

\begin{tabular}{|c|c|c|c|c|c|}
\hline $\mathrm{pH}$ & Viscosity Behaviour & Slip density $\left(\mathrm{gm} \mathrm{cm}^{-3}\right)$ & $\begin{array}{l}\text { Bulk sedimentation density } \\
\left(\mathrm{gm} \mathrm{cm}^{-3}\right)\end{array}$ & $\%$ Shrinkage & $\begin{array}{l}\text { Green density } \\
(\% \text { Theorotical })\end{array}$ \\
\hline \multicolumn{6}{|c|}{ (a) $80 \mathrm{wt} \% \mathrm{ZrO}_{2}+20 \mathrm{wt} \%$ water $+1.2 \mathrm{wt} \% \mathrm{M} 20 \mathrm{C}$} \\
\hline 1.26 & Pseudoplastic & 2.86 & 2.47 & 0.62 & 59.99 \\
\hline 3.11 & Newtonian & 2.86 & 2.58 & 0.08 & 71.98 \\
\hline 5.76 & Pseudoplastic & 2.86 & 2.47 & 1.03 & 45.06 \\
\hline 8.58 & Near Newtonian & 2.87 & 2.54 & 1.40 & 72.99 \\
\hline 10.16 & Newtonian & 2.86 & 2.66 & 0.16 & 77.94 \\
\hline 13.34 & Pseudoplastic & 2.86 & 2.44 & 0.13 & 50.27 \\
\hline \multicolumn{6}{|c|}{ (b) $75 \mathrm{wt} \% 12 \mathrm{Ce}-\mathrm{TZP}+25 \mathrm{wt} \%$ water $+1.0 \mathrm{wt} \% \mathrm{M} 20 \mathrm{C}$} \\
\hline 2.11 & Pseudoplastic & 2.93 & 2.58 & 0.21 & 47.51 \\
\hline 3.41 & Near Newtonian & 2.90 & 2.61 & 0.18 & 60.14 \\
\hline 6.06 & Pseudoplastic & 2.92 & 2.52 & 1.28 & 42.12 \\
\hline 8.16 & Near Newtonian & 2.89 & 2.69 & 1.01 & 72.19 \\
\hline 10.26 & Newtonian & 2.90 & 2.71 & 0.98 & 75.86 \\
\hline 13.04 & Pseudoplastic & 2.92 & 2.57 & 1.52 & 45.70 \\
\hline
\end{tabular}



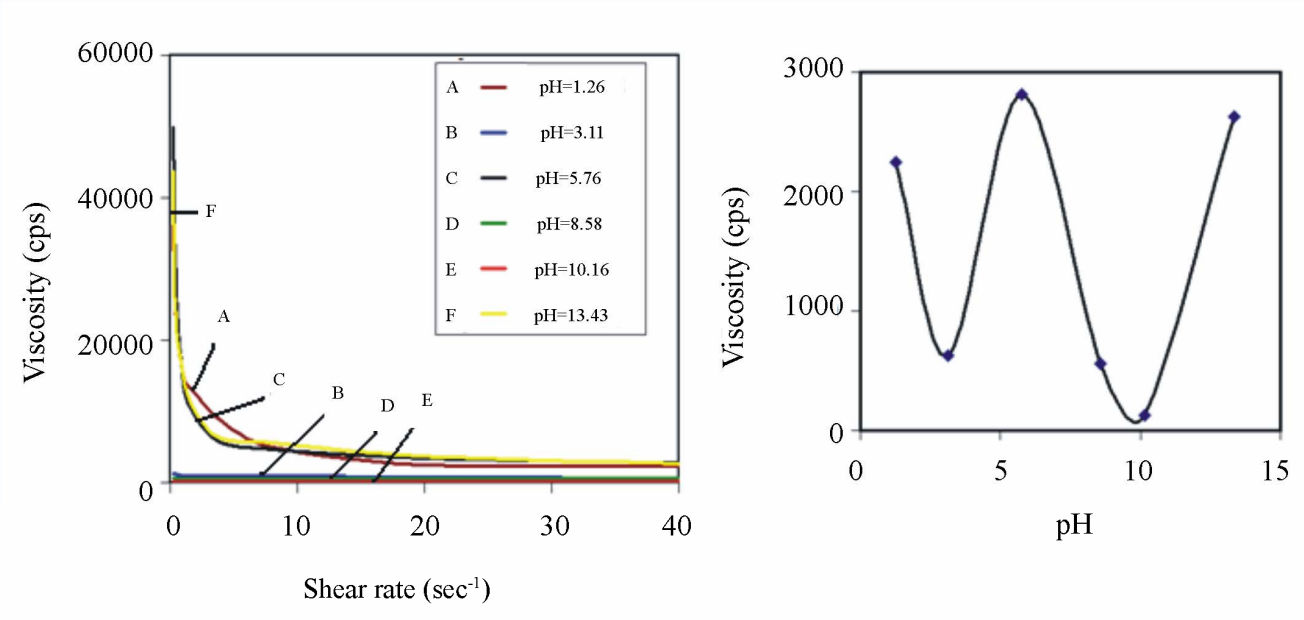

(a)

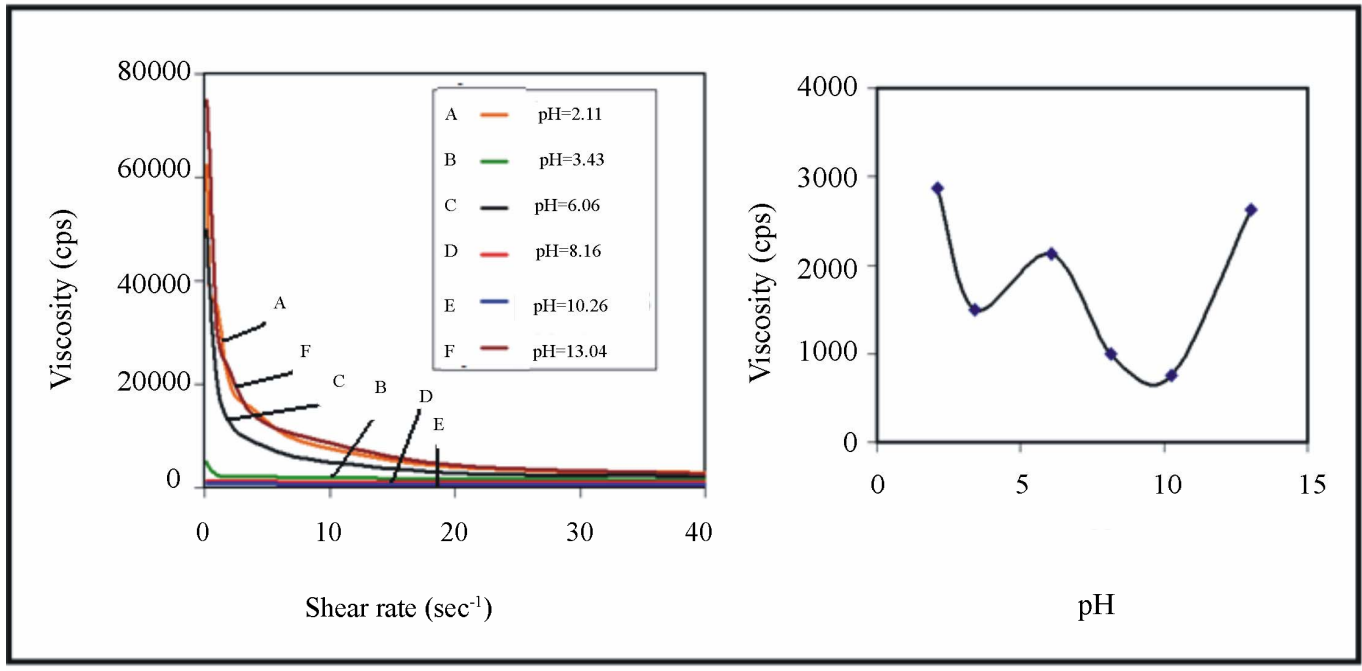

(b)

Figure 7. Plots of viscosity against shear rate for suspensions with $\mathrm{pH}$ values indicated and plots of viscosity against several $\mathrm{pH}$ values (at constant shear rate of $40 \mathrm{sec}^{-1}$ ). (a) $80 \mathrm{wt} . \%$ zirconia-20 wt.\% water-M20C deflocculant; (b) 75 wt.\% 12 Ce-TZP-25 wt.\% water-M20C deflocculant.

lated. The density of green bodies was also measured according to the Archimedes method. These results are also summarized in Table 2. For both the systems, the highest green density and low percent shrinkage corresponds to minimum viscosity of Newtonian behavior are observed. In these systems, the highest theoretical green density was $77 \%$ for $\mathrm{ZrO}_{2}$ and $75 \%$ for $12 \mathrm{Ce}-\mathrm{TZP}$. The acidic slips of $\mathrm{ZrO}_{2}$ and $12 \mathrm{Ce}-\mathrm{TZP}$ (both in water-M20C system) are found to be minute pits on the mould surface after casting. Basic slips however have a general roughening of the surface rather than pitting. The solid casting obtained from $\mathrm{ZrO}_{2}$ is white, good in nature and higher strength than the solid-cast obtained from $12 \mathrm{Ce}-\mathrm{TZP}$ and it has pale yellow in colour.

\section{CONCLUSIONS}

The results presented in this work enable us to draw the following conclusions:

1) Zirconia $\left(\mathrm{ZrO}_{2}\right)$ and ceria-stabilized zirconia (12 mol\% ceria in $\mathrm{ZrO}_{2}$ ) powders are synthesized by different dicarboxylates such as fumarate, succinate, tartarate and adipate precursor method.

2) Based on the results obtained from X-ray diffrac- 
tometry, particle size distribution, scanning electron microscopy and BET surface area measurements, $\mathrm{ZrO}_{2}$ and ceria-stabilized $\mathrm{ZrO}_{2} \quad(12 \mathrm{Ce}-\mathrm{TZP})$ powders obtained from adipate precursor are found to be good for slip casting. Both powders have tetragonal structure. The ceria addition is affected the powder characteristics. The grain size decreases with ceria content, which is accompanied by more effective tetragonal phase stabilization in this powder.

3) The intensity of shear during slip preparation, as controlled by the solid volume fraction, has a great influence on the dispersion efficiency, which, in turn, is reflected in the rheological characteristics of the suspensions and their packing ability on slip-casting. Preliminary test on the rheological behavior shows $80 \mathrm{wt} \%$ $\mathrm{ZrO}_{2}$ and $75 \mathrm{wt} \%$ 12Ce-TZP powders in distilled water and $\mathrm{M} 20 \mathrm{C}$ dispersant gives minimum viscosity and Newtonian flow behavior.

4) Rheological properties show minimum viscosity for the system $\mathrm{ZrO}_{2}$-water-M20C at $\mathrm{pH}=10.16$ and $12 \mathrm{Ce}-$ TZP-water-M20C at $\mathrm{pH}=10.26$. At these $\mathrm{pH}$ range, the particles are well dispersed and show high slip, green and sedimentation density. The green density seems even more reliable in the evaluation of the dispersing degree.

5) The solid casting obtained from $\mathrm{ZrO}_{2}$ powder is white, good in nature and higher strength than $12 \mathrm{Ce}-$ TZP powder and it has pale yellow colour.

\section{ACKNOWLEDGEMENTS}

The authors thank Dr Grathwhol from Universitat Bremen, Germany, for suggestions and helpful discussions. They also thank the Executive Director, Centre for Materials for Electronics Technology (C-MET) and Dr. C. V. Rode, National Chemical Laboratory (NCL), Pashan Road, Pune-411008, India, for the facilities given for part of the work.

\section{REFERENCES}

[1] Hannink, R.H.J., Kelly, P.M. and Muddle, B.C. (2000) Transformation toughening in zirconia-containing ceramics. Journal of the American Ceramic Society, 83(3), 461-487.

[2] Marray, E.P., Tsai, T. and Barnett, S.A. (1999) A directmethane fuel cell with a ceria-based anode. Nature, 400(6745), 649-651.

[3] Haase, F. and Sauer, F. (1998) The surface structure of sulfated zirconia: Periodic ab initio study of sulfuric acid adsorbed on $\mathrm{ZrO}_{2}(101)$ and $\mathrm{ZrO}_{2}(001)$. Journal of the American Chemical Society, 120(51), 13503-13512.

[4] Chandwick, A.V. (2000) Nanotechnology: Solid progress in ion conduction. Nature, 408(6815), 925-926.

[5] Steele, B.C.H. and Heinzel, A. (2001) Materials for fuel-cell technologies. Nature, 414(6861), 345-352.

[6] Wu, N.L., Wang, S.Y. and Rusakova, I.A. (1999) Inhibition of crystallite growth in the sol-gel synthesis of nano- crystalline metal oxides. Science, 285(5432), 1375-1377.

[7] Maczka, M., Lutz, E.T.G., Verbeck, H.J., Oskam, K., Meijerink, A., Hanuza, J. and Stuivinga, M. (1999) Spectroscopic studies of dynamically compacted monoclinic $\mathrm{ZrO}_{2}$. Journal of Physics and Chemistry Solids, 60(12), 1909-1914.

[8] Park, S., Vohs, J.M. and Gorte, R.J. (2000) Direct oxidation of hydrocarbons in a solid-oxide fuel cell. Nature 404(6775), 265-267.

[9] Cheung, T.K. and Gates, B.C. (1997) Activation of ethane in the presence of solid acids: Sulfated zirconia, ironand manganese-promoted sulfated zirconia, and zeolites. Journal of Catalysis, 168(2), 522-531.

[10] Sayama, K. and Arakawa, H. (1993) Photocatalytic decomposition of water and photocatalytic reduction of carbon dioxide over zirconia catalyst. Journal of Physical Chemistry, 97(3), 531-533.

[11] Shi, J.L. (1999) Relation between coarsening and densification in solid-state sintering of ceramics: Experimental test on superfine zirconia powder compacts. Journal of Materials Research, 14(4), 1389-1397.

[12] Subbarao, E.C. (1981) Advances in ceramics. Science and Technology of Zirconia, Heuer, A.H. and Hobbs, L.W., Eds., Elsevier, Amsterdam, 3, 1-24.

[13] Garvie, R.C., Hannink R.H. and Pascoe, R.T. (1975) Ceramic steel. Nature, 258(5537), 703-704.

[14] Yashima, M., Morimoto, K., Ishizawa, N. and Yoshimura, M. (1993) Zirconia-ceria solid solution synthesis and the temperature-time-transformation diagram for the $1: 1$ composition. Journal of the American Ceramic Society, 76(7), 1745-1750.

[15] Murugave, P., Kalaiselvam, M., Raju, A.R. and Rao, C.N.R. (1997) Sub-micrometre spherical particles of $\mathrm{TiO}_{2}, \mathrm{ZrO}_{2}$ and PZT by nebulized spray pyrolysis of metal-organic precursors. Journal of Materials Chemistry, 7(8), 1433-1438.

[16] Li, M., Feng, Z., Xiong, G., Ying, P., Xin, Q. and Li, C. (2001) Phase transformation in the surface region of zirconia detected by uv raman spectroscopy. Journal of Physical Chemistry B, 105(34), 8107-8111.

[17] Yashma, M., Kakihana, M., Ishii, K., Ikuma Y. and Yoshimura, M. (1996) Synthesis of metastable tetragonal ( $\left.\mathrm{t}^{\prime}\right)$ zirconia-calcia solid solution by pyrolysis of organic precursors and coprecipitation route. Journal of Materials Research, 11(6), 1410-1420.

[18] Duh, J.G., Dai, H.T. and Hsu, W.Y. (1988) Synthesis and sintering behaviour in $\mathrm{CeO}_{2}-\mathrm{ZrO}_{2}$ ceramics. Journal of Materials Science, 23(6), 2786-2791.

[19] Sato, T., Dosaka, K., Yoshika, T., Okuwaka, A., Yorii, K. and Onodera, Y. (1992) Sintering of ceria-doped tetragonal zirconia crystallized in organic solvents, water, and air Journal of the American Ceramic Society, 75(3), 552-556.

[20] Maschio, S., Baxhiorrini A. and Lucchini, E. (1998) Sintering behaviour of mechanically alloyed and coprecipitated 12Ce-PSZ powders. Journal of Materials Science, 33(13), 3437-3441.

[21] Yashima, M., Ohtake, K., Kakihana, M. and Yoshimura, M. (1994) Synthesis of metastable tetragonal ( $t$ ') zirconiaceria solid solutions by the polymerized complex method. Journal of the American Ceramic Society, 77(10), 27732776. 
[22] Caruso, R., Benavidez, E., de Sanctis, O., Caracoche, M.C., Ravas, P.C., Cervera, M., Caneiro, A. and Serquis, A. (1997) Phase structure and thermal evolution in coating films and powders obtained by the sol-gel process: Part II. $\mathrm{ZrO}_{2}-2.5 \mathrm{~mol} \% \mathrm{Y}_{2} \mathrm{O}_{3}$. Journal of Materials Research, 12(10), 2594-2601.

[23] Lumas, D.G., Lascalea G.E. and Walsoe de Reca, N.E. (1998) Synthesis and characterization of nanocrystalline powders for partially stabilized zirconia ceramics. Journal of the European Ceramic Society, 18(9), 1217-1221.

[24] Venkatachari, K.R., Huang, D., Ostrander, S.P., Shulze W.A. and Stangle, G.C. (1995) Preparation of nanocrystalline yttria-stabilized zirconia. Journal of Materials Research, 10(3), 756-761.

[25] Xiaming, D., Qingfeng, L. and Yuying, T. (1993) Study of phase formation in spray pyrolysis of $\mathrm{ZrO}_{2}$ and $\mathrm{ZrO}_{2}-\mathrm{Y}_{2} \mathrm{O}_{3}$ powders. Journal of the American Ceramic Society, 76(3), 760-762.

[26] Srinivasan, R., DeAngeles, R. and Davis, B.H. (1986) Factors influencing the stability of the tetragonal form of zirconia. Journal of Materials Research, 1(4), 583-588.

[27] Kresge, C.T., Leonowicz, M.E., Roth, W.J., Vartuli, J.C., and Beck, J.S. (1992) Ordered mesoporous molecular sieves synthesized by a liquid-crystal template mechanism. Nature, 359(6397), 710-712.

[28] Huo, Q., Margolese, D.I., Ciesla, U., Feng, P., Gier, T.E., Sieger, P., Leon, R., Petroff, P.M., Schuth, B. and Stucky, G.D. (1994) Generalized synthesis of periodic surfactant/inorganic composite materials. Nature, 368(6469), 317-321.

[29] Wang Y., Yin, L., Palhcik, O., Hacohen, Y.R., Koltypin, Y. and Gedanken, A. (2001) Sonochemical synthesis of layered and hexagonal yttrium-zirconium oxides. Chemistry of Materials, 13(4), 1248-1251.

[30] Liang, J., Jiang, X., Liu, G., Deng, Z., Zhuang, J., Li, F. and Li, Y. (2003) Characterization and synthesis of pure $\mathrm{ZrO}_{2}$ nanopowders via sonochemical method. Materials Research Bulletin, 38(1), 161-168.

[31] Coyle, T.W., Coblenz, W.S. and Bender, B.A. (1983) Toughness, strength, and microstructures of sintered $\mathrm{CeO}_{2}$-doped $\mathrm{ZrO}_{2}$ alloys. American Ceramic Society Bulletin, 62(12), 966-967.

[32] Heathote, R. (1993) Sustainable humanosphere: Bulletin of research institute for sustainable humanosphere. American Ceramic Society Bulletin, 72(6), 123-128.

[33] Taguchi, H., Takahashi, Y. and Miyamoto, H. (1985) Slip casting of partially stabilized zirconia. American Ceramic Society Bulletin, 64(2), 325-329.

[34] Lange, F.F. (1989) Powder processing science and technology for increased reliability. Journal of the American Ceramic Society, 72(1), 3-15.

[35] Raedy, M.J. (1993) Optimized processing ceramics. International Journal of Applied Ceramic Technology, 47-53.

[36] Taguchi, H., Takahashiand Y. and Miyamoto, H. (1985) Effect of milling on slip casting of partially stabilized zirconia. Journal of the American Ceramic Society, 68(10), C264-C265.

[37] Leong, Y.K., Katiforis, N., Harding, D.B.O.C., Healy T.W. and Boger, D.V. (1993) Polymeric stabilization of colloidal dispersions. Journal of Materials Proceedings on Manufacturing Science, 1, 445-453.

[38] Leong, Y.K., Boger, D.V. and Parris, D. (1991) Surface chemistry and rheological properties of zirconia suspensions. Journal of Rheology, 35(1), 149-165.

[39] Hashiba, M., Okamoto, H., Nurishi, Y. and Hiramatsu, K. (1989) Dispersion of $\mathrm{ZrO}_{2}$ particles in aqueous suspensions by ammonium polyacrylate. Journal of Materials Science, 24(3), 873-876.

[40] Nikumbh, A.K., Schmidt, H., Martin, K. and Porz, F. (1991) Slip casting of partially stabilized zirconia. Journal of Materials Science, 26(13), 3649-3656.

[41] Suarez, G., Albano, M.P., Garrido, L.B. and Aglietti, E.F. (2007) Dispersion of concentrated aqueous yttria-stabilized zirconia with ammonium polyacrylate. Ceramics International, 33(6), 925-929

[42] Shojai, F., Pettersson, A.B.A., Mantyla, T. and Rosenholm, J.B. (2000) Electrostatic and electrosteric stabilization of aqueous slips of $3 \mathrm{Y}-\mathrm{ZrO}_{2}$ powder. Journal of the European Ceramic Society, 20(3), 277-283.

[43] Joint Committee on Powder Diffraction Standards, PDF No. 17-923.

[44] Dodd, A.C. and McCornick, P.G. (1999) Synthesis and processing of ultrafine Mg-PSZ powder. Journal of Metastable and Nanocrystalline Materials, 312-314, 221228.

[45] Nettleship, I. and Stevens, R. (1987) Tetragonal zirconia polycrystal (TZP) - a review, International Journal of High Technology Ceramics, 3(1), 1-32.

[46] Klug, H.P. and Alexander, L.E. (1954) X-Ray diffraction procedure. Wiley-Interscience, New York, Ch.9.

[47] MacGeary, R.K. (1961) Mechanical packing of spherical particles. Journal of the American Ceramic Society, 44(10), 513-522.

[48] Laarz, E., Zhmud, B.V. and Bergstroem, L. (2000) Dissolution and deagglomeration of silicon nitride in aqueous medium. Journal of the American Ceramic Society, 83(10), 2394-2400.

[49] Tari, G., Ferreira, J.M.F. and Lyckfeldt, O.L. (1998) Influence of the stabilising mechanism and solid loading on slip casting of alumina. Journal of the European Ceramic Society, 18(5), 479-486.

[50] Sigmund, W.M., Bell, N.S. and Bergstrom, L. (2000) Novel powder-processing methods for advanced ceramics. Journal of the American Ceramic Society, 83(7), 1557-1574.

[51] Bergstrom, L. (1998) Shear thinning and shear thickening of concentrated ceramic suspensions. Colloids and Surfaces A: Physicochemical and Engineering Aspects, 133(1-2), 151-155.

[52] Moreno, R. (1992) The role of slip additives in tapecasting technology. Part I: Solvents and dispersants. American Ceramic Society Bulletin, 71(10), 1521-1531.

[53] Smart, S.T.C.R. and Nowotny, J. (1998) Ceramic interface-properties and applications. IOM Communications Ltd., London, 433-460.

[54] Greenwood, R. and Bergstrom, L. (1997) Electroacoustic and rheological properties of aqueous $\mathrm{Ce}-\mathrm{ZrO}_{2}(\mathrm{Ce}-\mathrm{TZP})$ suspensions. Journal of the European Ceramic Society, 17(4), 537-548. 